\title{
INTEGRAL INDICES FOR QUALITY ASSESSMENT OF PULP AND PAPER MILL EFFLUENTS
}

\author{
KONSTANTIN BOGOLITSYN ${ }^{1}$, MARIA GUSAKOVA ${ }^{1}$, NINA SAMSONOVA ${ }^{1}$, NATA- \\ LIA SELIVANOVA ${ }^{1}$, ALEXSANDRA POCHTOVALOVA ${ }^{2}$ \\ ${ }^{1}$ Institute of Ecological Problems of the North, Ural Division, Russian Academy of Sciences; nab. Severnoi Dviny, \\ 23, 163000, Arkhangelsk, Russia; e-mail: gavrilova.iepn@yandex.ru \\ ${ }^{2}$ Northern (Arctic) Federal University named after M.V. Lomonosov; nab. Severnoi Dviny, 17, 163000, Arkhangelsk, \\ Russia; e-mail: apochtovalova@yandex.ru
}

\begin{abstract}
Bogolitsyn K., Gusakova M., Samsonova N., Selivanova N., Pochtovalova A.: Integral indices for quality assessment of pulp and paper mill effluents. Ekológia (Bratislava), Vol. 33, No. 1, p. 60-66, 2014.

The first part of this investigation studied complex nature of chemical oxygen demand (COD) parameter on local and overall effluents, which were obtained from two pulp and paper mills, located in the Northwest region of Russia. Contribution of individual compounds and fractions of matters having different chemical nature to COD for these effluents was established. The second part of this study shows that, qualitative and quantitative characteristics of priority pollutants and their contribution to COD for different pulp and paper mills are not the same, though these mills use similar technologies and produce similar products.
\end{abstract}

Key words: Best available technology (BAT), Chemical oxygen demand (COD), Industrial effluents, Resin and fatty acids (RFAs), Suspended solids (SS).

\section{Introduction}

Pulp and paper production is one of the industries that consume large quantities of water. Effluents from pulp and paper mill are highly polluted and contain numerous organic and mineral substances. It is because of this reason that they pose environmental danger to the natural water ecosystems and human health (Gusakova et al., 2011).

Trends in the development of complex wood-processing industry are determined by solutions to environmental problems, thereby reducing the anthropogenic impact on the environment. On the one hand, from the position of 'green chemistry', solutions to these problems consist in the introduction of the best available technology (BAT) principles, defining development of technological processes, equipment design, methods of treating effluents and gas emissions and maximum reduction of waste (Lichutina et al., 2005; Bogolitsyn et al., 2010; Brovko et al., 2008). On the other hand, these solutions involve the creation of modern highly informative methods of environmental control and monitoring of quality of technological water and natural ecosystems in the pulp and paper production area. 
Analysis of the main technological processes of complex wood-processing industry allows us to conclude that the composition and the quality of effluents will be determined mainly by chemical processes, occurring between the main components of wood and technological pulp, the chemical nature of components of the used liquors and the technological equipment.

Thus, effluents from pulp and paper enterprise can be divided into two groups:

- Liquor-containing effluent (pulp production)

- $\quad$ Fibre-containing effluent (paper and board production)

The liquor-containing effluent is mainly formed by dissolved organic substances having lignin and carbohydrate character (wood extractives, including resin acids and fatty acids), sulphur- and chloride-containing compounds, minerals and specific pollutants (chlorinated phenols). If present in sufficient concentrations, many of the compounds in effluents would be toxic to wildlife if released untreated.

The composition of fibre-containing effluent from paper and board mill depends on the type of products and includes pulp fibres, wood pulp, sizing agents, fillers, dyes, latex and emulsions. The specific composition of pollutants depends on the composition of paper or cardboard. Thus, quantitative and qualitative composition of effluent varies depending on the implemented technologies, raw materials and chemicals used (Pochtovalova, 2002; Soboleva, 2007). Table 1 presents the characteristics of the component composition of various effluents.

T a b l e 1. Characteristics of component composition of various effluents.

\begin{tabular}{|c|c|c|c|c|c|c|c|}
\hline \multirow[b]{2}{*}{ Effluent } & \multicolumn{7}{|c|}{ Parameter, unit } \\
\hline & $\begin{array}{c}\mathrm{COD}, \\
\mathrm{mg} / \mathrm{L}\end{array}$ & $\begin{array}{c}\mathrm{SS}, \\
\mathrm{mg} / \mathrm{L}\end{array}$ & $\begin{array}{c}\text { Phenol, } \\
\mathrm{mg} / \mathrm{L}\end{array}$ & \begin{tabular}{|c|} 
Formaldehyde, \\
$\mathrm{mg} / \mathrm{L}$
\end{tabular} & $\begin{array}{c}\text { Methanol, } \\
\mathrm{mg} / \mathrm{L}\end{array}$ & $\begin{array}{c}\text { Chloride, } \\
\mathrm{mg} / \mathrm{L}\end{array}$ & $\begin{array}{c}\text { sulphide, } \\
\text { mg/L }\end{array}$ \\
\hline Kraft pulping & & & & & & & \\
\hline - Cooking process & 483 & 61 & 0.5 & 0.1 & 35 & 30.9 & 72.5 \\
\hline - Bleaching process & 762 & 155 & 0.1 & 0.6 & 23 & 300.9 & 454.5 \\
\hline - Evaporation process & 1360 & 50 & 5.4 & 0.4 & 595 & 58.3 & 385.5 \\
\hline $\begin{array}{l}\text { - Causticization and } \\
\text { regeneration of lime } \\
\text { process }\end{array}$ & 80 & 115 & 0.01 & 0.2 & 0.1 & 43.2 & 979.6 \\
\hline Mechanical pulp process & 4100 & 890 & 1.6 & 0.6 & 12.7 & 32.7 & 234.5 \\
\hline
\end{tabular}

In the light of the above, pulp and paper mill effluent is a multi-component aqueous system, containing the following main groups of substances:

- $\quad$ Suspended solids

- Dissolved inorganic components

- Dissolved organic components (Gusakova et al., 2009).

The presence of these components determines the choice of effluent discharging schemes and treatment technologies. The treatment of effluents in pulp and paper mill is typically composed of neutralization, clarification, biological treatment and release into receiving water bodies (Tran, 2009).

Taking into account the multi-component composition of pulp and paper effluents, from an environmental control viewpoint, it is legal to determine the diverse chemical nature and 
the toxicity amount in the pollutants. However, multivariance of indices for assessment of danger class of substances, incomparability of assessment by some indices, low level of accuracy of standardized methods, lead to difficulties in obtaining a reliable and accurate information for environmental decisions.

These drawbacks can be eliminated by developing the wastewater quality system which is based on integral indicators. For European enterprises work according to the BAT principles, the list of regulated indices for control of discharged effluents consists of the chemical oxygen demand (COD), biochemical oxygen demand (BOD), suspended solids (SS), absorbable organic Halogens (AOX), total nitrogen (N) and total phosphorus (P) (Bogolitsyn et al., 2010).

The objective of our study was to evaluate the feasibility of using COD how priority, integral wastewater quality parameter for effluents from various operations of pulp and paper mill.

The first part of this investigation focused on the contribution of fractions and individual compounds of effluents to COD. The second part compares qualitative and quantitative characteristics of priority pollutants and their contribution to COD for two pulp and paper mills.

\section{Material and methods}

For this investigation we used the effluent samples taken from the wood handling, kraft pulping process, mechanical pulping process and overall effluents from two integrated pulp and paper mills, located in the Northwest region of Russia. These mills meet the environmental requirements for similar enterprises in the EU (Bogolitsyn et al., 2010). The samples were stored at $5^{\circ} \mathrm{C}$ in a refrigerator, and used within one week.

The COD was the main parameter used to evaluate the concentration of effluent pollutants. We analysed the COD by photometric method as per the Russian standard. The COD of suspended solids was determined by the difference between COD of unfiltered and filtered samples: $\mathrm{COD}_{\mathrm{SS}}=\mathrm{COD}_{\text {unfil }}-\mathrm{COD}_{\mathrm{fil}}$, where $\mathrm{COD}_{\mathrm{sS}}$ is the $\mathrm{COD}$ of suspended solids, $\mathrm{mg} / \mathrm{L} ; \mathrm{COD}_{\text {unfil }}$ is the COD of unfiltered water samples, $\mathrm{mg} / \mathrm{L}$; and $\mathrm{COD}_{\text {fil }}$ is the COD of filtered water samples, $\mathrm{mg} / \mathrm{L}$. The contribution of suspended solids to the total $\mathrm{COD}_{\text {total }}, \%$, is given by

$$
N_{\mathrm{COD}_{\mathrm{SS}}}=\frac{\mathrm{COD}_{\text {unfil }}-\mathrm{COD}_{\mathrm{fil}}}{\mathrm{COD}_{\text {unfil }}} \cdot 100 \% \text {, }
$$

where $N_{\mathrm{COD}_{\mathrm{SS}}}$ is the contribution of suspended solids to COD ${ }_{\text {total, }} \%$.

Method of ion exchange was used for separation of organic and mineral components of effluents.

The $\mathrm{COD}_{\min }$ of the mineral component was determined by the difference between COD of filtered wastewater sample and COD of samples treated with ion-exchange resins: $\mathrm{COD}_{\min }=\mathrm{COD}_{\mathrm{fil}}-\mathrm{COD}_{\text {exch }}$, where $\mathrm{COD}_{\min }$ is the $\mathrm{COD}$ of dissolved mineral components, $\mathrm{mg} / \mathrm{L} ; \mathrm{COD}_{\text {exch }}$ is the COD of dissolved organic components of the sample, $\mathrm{mg} / \mathrm{L}$. The contribution of dissolved mineral components to $\mathrm{COD}_{\text {total }} \%$ is

$$
N_{\mathrm{COD}_{\text {min }}}=\frac{\mathrm{COD}_{\text {fil }}-\mathrm{COD}_{\text {exch }}}{\mathrm{COD}_{\text {unfil }}} \cdot 100 \%
$$

where $N_{\mathrm{COD}_{\min }}$ is the contribution of dissolved mineral component to $\mathrm{COD}_{\text {total }}, \%$.

The $\mathrm{COD}_{\text {org }}$ of organic components was determined by the difference between COD of filtered effluent samples and COD of mineral component: $\mathrm{COD}_{\text {org }}=\mathrm{COD}_{\mathrm{fil}}-\mathrm{COD}_{\min }$, where $\mathrm{COD}_{\text {org }}$ is the COD of dissolved organic components, $\mathrm{mg} / \mathrm{L}$. Contribution of dissolved organic components to $\mathrm{COD}_{\text {total }}$ is

$$
N_{\mathrm{COD}_{\text {org }}}=\frac{\mathrm{COD}_{\text {fil }}-\mathrm{COD}_{\text {min }}}{\mathrm{COD}_{\text {unfil }}} \cdot 100 \% \text {, }
$$


where $N_{\mathrm{COD}_{\text {org }}}$ is the contribution of dissolved organic components to $\mathrm{COD}_{\text {total }}$ \%.

Representative fractions of the main groups of components of local and overall effluents from pulp and paper enterprises were divided by using the developed scheme of fractionation given in Fig. 1 (Pochtovalova, 2002).

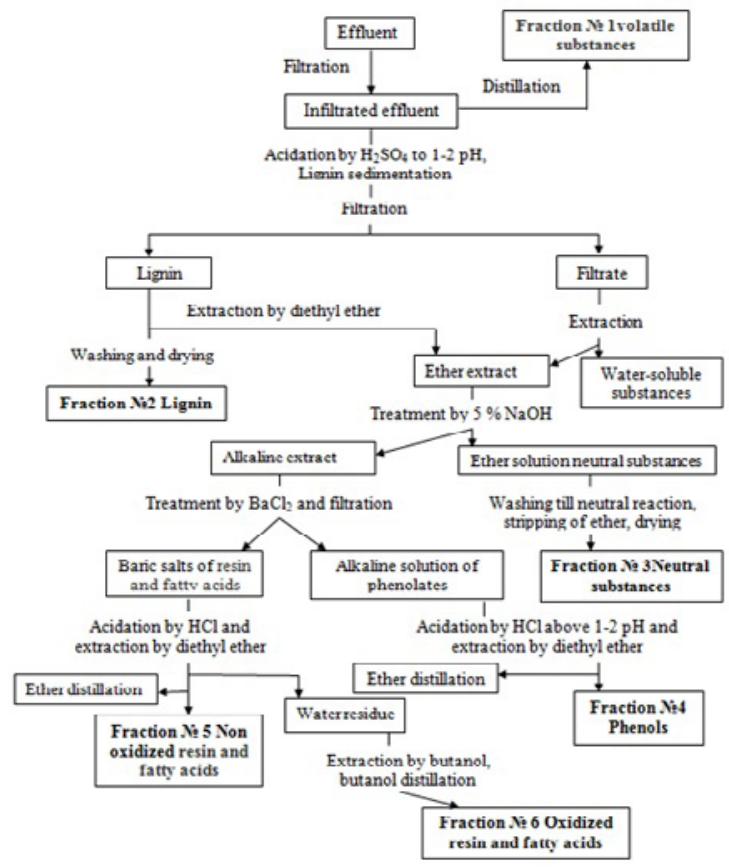

Fig. 1. Fractionation scheme for the main groups of effluents components.

\section{Results and discussion}

According to the work of Lehtinen (Lehtinen, Tana, 2000), organic components make about $75 \%$ of $\mathrm{COD}_{\text {total }}$ and mineral components about $25 \%$. Fulfilled work showed that contribution of suspended solids and dissolved mineral compounds to $\mathrm{COD}_{\text {total }}$ for different sampling points of effluent discharge varies widely. Table 2 presents contribution of suspended and mineral substances to $\mathrm{COD}_{\text {total }}$ for various effluents.

$\mathrm{T}$ a b le 2. Contribution of suspended solids and mineral substances to $\mathrm{COD}_{\text {total }}$ for various effluents.

\begin{tabular}{|l|c|}
\hline \multicolumn{1}{|c|}{ Effluents } & Contribution to COD total $^{\prime}$ rel. \% \\
\hline Bleached kraft & $30-40$ \\
- Bleaching step & $20-52$ \\
- Overall effluent & $20-50$ \\
\hline Unbleached kraft and cardboard production & $34-75$ \\
\hline Wood handling & $68-72$ \\
\hline Mechanical pulp & 12.50 \\
\hline Effluent before biological treatment & 10.60 \\
\hline Effluent after biological treatment & \\
\hline
\end{tabular}


Organic part of pulp and paper effluent has very important meaning. While the similar technological processes, but varying of technological parameters, types of raw materials, chemicals, equipment, effluents quality is characterized by similar values of COD. However, analysis of the effluents composition shows that there is difference both in quantitative content of individual components and groups of organic compounds and in their chemical and functional nature. Therefore, the use of the COD for environmental analytical control requires identification of priority pollutants and determination of their contribution to $\mathrm{COD}_{\text {total }}$ for each pulp and paper mill.

Contribution of the main groups of components to $\mathrm{COD}_{\text {total }}$ was defined using the gauge dependences of COD on the concentration of substances were plotted for determination of COD of lignin substances, neutral substances, non-volatile phenols and resin and fatty acids (RFAs). Table 3 presents value of ' $a$ ' parameter for the equation $\mathrm{COD}=a^{\star} C$, for local and overall effluents from two pulp and paper mills, where $C$ is the concentration of individual fraction. The correlation coefficients $R^{2}$ varied from 0.94 to 0.99 .

T a b le 3. Value of 'a'» parameter in various effluents.

\begin{tabular}{|l|c|c|c|c|}
\hline \multirow{2}{*}{\multicolumn{1}{|c|}{ Effluents }} & \multicolumn{4}{c|}{ Parameter } \\
\cline { 2 - 5 } & $\begin{array}{c}\text { Lignin } \\
\text { compounds }\end{array}$ & $\begin{array}{c}\text { Neutral } \\
\text { substances }\end{array}$ & $\begin{array}{c}\text { Non-volatile } \\
\text { phenols }\end{array}$ & $\begin{array}{c}\text { Resin and fatty } \\
\text { acids (RFAs) }\end{array}$ \\
\hline Bleached pulp production & & & & \\
- Effluent from oxygen-alkaline step of bleaching & 0.99 & 1.29 & 0.58 & 2.01 \\
- Effluent from D step of bleaching & 1.03 & 1.2 & 0.63 & 1.27 \\
- Overall effluent & 1.88 & 2.15 & 1.89 & 2.06 \\
\hline Unbleached pulp production & 1.55 & 0.95 & 1.36 & 1.91 \\
\hline Effluent before biological treatment & & & & 0.53 \\
Mill No. 1 & 1.66 & 1.03 & 0.13 & 2.18 \\
Mill No. 2 & 2.02 & 0.89 & 2 & 1.37 \\
\hline Effluent after biological treatment (mill No. 2) & 1.71 & 1.04 & 1.84 & \\
\hline
\end{tabular}

Concentration of individual fraction of organic substances was determined according to protolytic properties and solubility using developed fractionation scheme (Fig. 1). Fractions of the volatile components (phenols volatile with steam, methanol, turpentine and formaldehyde) and lignin compounds contribute the largest to $\mathrm{COD}_{\text {org }}$. The total contribution of these components to $\mathrm{COD}_{\text {org }}$ for the investigated effluents is from 59 to 85 rel. \%.

Material balance of $\mathrm{COD}_{\text {total }}$ for the overall industrial effluents for two pulp and paper mills using the same technologies and producing similar range of products is given in Fig. 2.

Suspended solids contribute the largest to $\mathrm{COD}_{\text {total }}$ for untreated industrial effluents. The effective removal of suspended solids by mechanical treatment allows reduction of $\mathrm{COD}_{\text {total }}$ to about 30-40 rel. \%.

Fractions of the volatile substances and lignin compounds make a maximum contribution to the overall balance of COD for untreated effluents (19-33 rel. \% and 12-20 rel. \%, respectively). After passing the biological treatment system, the contribution of volatile substances fraction to $\mathrm{COD}_{\text {total }}$ reduces up to 5-10 rel. \%. 
However, not all organic compounds are bio-oxidized by biological treatment. Technology of biological treatment allows assimilating the group of the volatile and low-molecular phenol components effectively. The most part of high-molecular fraction of lignin compounds and extractives are difficult to oxidize, pass through the system of biological treatment and release into receiving water bodies.

The contribution of fraction of lignin substances to $\mathrm{COD}_{\text {total }}$ reduces approximately two times. Contribution of non-volatile phenol substances to $\mathrm{COD}_{\text {total }}$ is about 1-3 rel. \%. And contribution of extractives is $0.7-7.7$ rel. \%. Thus, $\mathrm{COD}_{\text {org }}$ reduces about five times after passing the biological treatment; COD of the volatile components reduces more than 10 times and COD of lignin substances only two times.

It is also necessary to pay specific attention to dissolved mineral part of composition of industrial effluents of pulp and paper mill. As shown in Fig. 2, the contribution of inorganic substances to $\mathrm{COD}_{\text {total }}$ is about 30 rel. \%. But after biological treatment, organic compounds are oxidized and the contribution of components to $\mathrm{COD}_{\text {total }}$ changes. The contribution of inorganic substances to $\mathrm{COD}_{\text {total }}$ achieves about 70 rel. \%. Thereby mineral compounds go through the process into receiving water bodies.

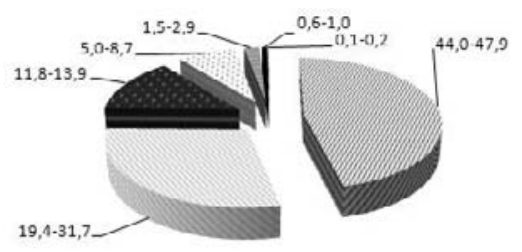

a)

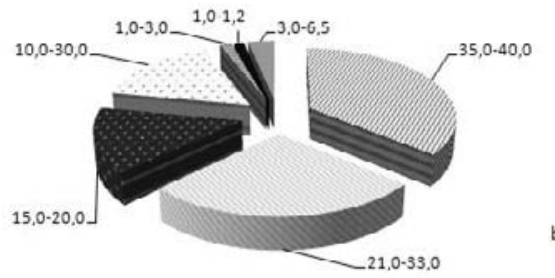

b)

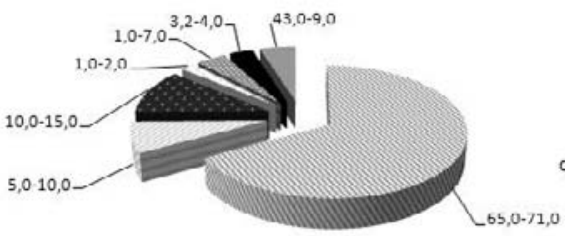

* suspended substances mineral substances

volatile phenols lignin substances

₹ non-volatile phenols neutral substances

= RFA

Fig. 2. Material balance of COD for effluents, rel.\%; a) overall effluent (mill â_1),b) overall effluent (mill â_ 2), effluent after biological treatment.

\section{Conclusion}

Results of fulfilled work have shown that COD is a function of the concentration of pollutants, having different chemical nature, contained in pulp and paper effluents. However, the formal transfer of qualitative and quantitative assessments of the priority pollutants and their contribution to $\mathrm{COD}_{\text {total }}$ from one mill to another, though they use the same technologies and produce similar products, is not correct.

Insignificant alterations of technological processes, such as reconstruction of the production and replacement of used chemicals, will change the quality of effluents. For the improvement of wastewater treatment processes and the achievement of the established standards of wastewater quality, it is necessary to study the contribution of individual components and fractions of compounds to the integrated index. Therefore, solution to such ecological and analytical problems provides a necessity for carrying out the researches at each mill, by using 
a common methodology of carrying out the analytical work. This analytical method can to be useful for other industries to organize efficient analytical quality control of wastewater as well as surface water.

\section{Acknowledgements}

This work was financially supported by RFFI grant 12-03-00446-a. We thank Joint use center of scientific equipment 'Critical Technologies of Russian Federation in the Field of Environmental Security in Arctic' of Institute of Ecological Problems of the North, Ural Division, Russian Academy of Sciences and Joint use center of scientific equipment 'Arctic' of Northern (Arctic) Federal University named after M.V. Lomonosov where all the experiments were conducted. The study was partially funded by the Ministry of Education and Science of Russian Federation.

\section{References}

Bogolitsyn, K., Soboleva, T. \& Gusakova M. (2010). Scientific bases of environmental analytical control of pulp and paper production effluents. Yekaterinburg: UD RAS.

Brovko, O., Gusakova M. \& Lichutina T. (2008). Technical approach to the monitoring of the effluent, coming from pulp and paper enterprises. In The XIV International Symposium in the Field of Pulp, Paper, Packaging and Graphics (pp. 125-127). Serbia.

Gusakova, M., Pochtovalova, A., Selivanova N. \& Bogolitsyn K. (2009). Ecological and analytical aspects of the formation and evaluation of pulp and paper production wastewaters. In 10th International Scientific Conference 'The latest technology in the manufacture of paper' (pp. 19-25). Karavaevo, Russia.

Gusakova, M., Bogolitsyn, K. \& Gavrilova N. (2011). Influence of activities of complex wood processing enterprises of the European north of Russia on the quality of surface water. Acta Hydrologica Slovaca, 12(2), 171-176.

Lehtinen, K. \& Tana J. (2000). When is further of low COD in pulp and paper mill effluents environmentally defendable. In The IX International Conference on Environmental Impacts of Pulp and Paper Industry (pp. 55-63). Helsinki, Finland.

Lichutina, T., Miskevich, I., Brovko O. \& Gusakova M. (2005). Optimization of standardization of discharge of effluents from PPI. Yekaterinburg: UD RAS. Pochtovalova, A`. (2002). Ecological and analytical assessment of chemical oxygen demand as integral indicators of pulp and paper production effluents. PhD thesis, ASTU, Russia.

Soboleva, T. (2007). Priority indicators of environmental control of effluents in the technological standardization of pulp and paper production. $\mathrm{PhD}$ thesis, ASTU, Russia.

Tran, A. (2009). Removal of COD and color loads in bleached Kraft pulp effluents using ozone. Tappi: J., 4, 4-11. 